\title{
STUDY ON BEHAVIOR ON HIGH STRENGTH CRIMPED STEEL FIBRE REINFORCED CONCRETEFOR GRADE M90
}

\author{
Vijay M. Mhaske ${ }^{1}$, Rahul D. Pandit ${ }^{2}$, A. P. Wadekar ${ }^{3}$ \\ ${ }^{I}$ P.G. Student (M.E-Structures), Department of Civil Engineering, Peoples Education Society's PES College of \\ Engineering, Nagsenvana, Aurangabad, Maharashtra State, 431002, India \\ ${ }^{2}$ Assistant Professor, Department of Civil Engineering, Peoples Education Society's PES College of Engineering, \\ Nagsenvana, Aurangabad, Maharashtra State, 431002, India \\ ${ }^{3}$ Professor \& Principal of Peoples Education Society's PES College of Engineering, Nagsenvana, Aurangabad, \\ Maharashtra State, 431002, India
}

\begin{abstract}
The use of High Strength Concrete (HSC) is on rise. HSC is very strong in compression but it is relatively brittle material and week in tension. Crimped steel Fibres are added to improve its ductility by bridging internal cracks. Experimental study is carried out to assessment of mechanical properties of high strength fibre reinforced concrete (HSFRC) for M90 grade. High strength concrete (HSC) is made with appropriate cementitiousmaterials i.e. cement fly ash and silicaby DOE mix design method. The fibre volume fraction is used 0 to $4 \%$ at $0.5 \%$ interval. Total 54 memberswere casted and tested for cube (100 X $100 \mathrm{X} 100) \mathrm{mm}$ and cylinder $(150 \times 300) \mathrm{mm}$ each. Total members cured for 7 and 28 days in curing tank of civil engineering concrete technology laboratory.
\end{abstract}

Keywords: HSFRC, CESF, Fly Ash, Silica fume.

\section{INTRODUCTION}

Now a days, high strength concrete (HSC) is becoming an attractive alternatively to traditional normal strength concrete (NSC) for important work as well as high rise buildings. High strength concretes more than $60 \mathrm{Mpa}$ are often used in a wide range of applications. High strength concrete (HSC) have low workability due that it becomes harsh. It has high strength and high durability. ACI (American concrete Institute) has defined HSC as a high strength concrete in which certain characteristics are developed for a particular application and environment. Under the ACI definition durability is optional and this has led to a number of HSC structures, which should theoretically have had very long services lives, exhibiting durability associated distress early in their lives. ACI also defines a high-strength concrete as that has a specified compressive strength for design of 6,000 psi (41 $\mathrm{Mpa}$ ) or greater. Cement high strength concrete can molded to any desired shapes in growing industrial activities and construction industry. It has closely related with more human beings and their day-to-day life activities and it is widely used as construction material in whole of the world, and it is slightly difficult to find another material of construction as versatile as high strength concrete. High strength concrete is nothing but an artificial stone resulting from the hardening of mixture of cement, sand, coarse aggregate, water and sometimes mineral and chemical admixtures. Admixtures and cementitious material can also add to enhance properties of high strength concrete in fresh and hardened state.
Thousands of small fibers are dispersed and distributed randomly in the high strength concrete during mixing for improve high strength concrete properties in all directions. Fibers help to improve the post- peak ductility performance, pre-crack tensile strength, impact strength, fatigue strength, and eliminate temperature and shrinkage cracks.High strength concrete is inherently a brittle material, with low tensile strength and limited ductility. Due to these properties, the normal high strength concrete has some limitation for application in very impotent structure, such as high-rise building, road pavements, long span bridges and construction of chimneys. The high strength concrete not only increases the strength of concrete but also it reduced the permeability. High strength concrete is generally, used for increasing the durability, tensile strength, modulus of elasticity and flexural strength of concrete.

\subsection{Necessity}

- They have higher modulus of elasticity

- They have a better bonding with the steel bar embedded in it.

- They can used to control plastic shrinkage cracking.

- They help in saving material due to providing less cross section.

- They provide tough and durable

\subsection{Objectives}

This investigation deals with the behavior of Crimped steel Fibre on High strength Fibre Reinforced concrete (HSFRC) composite with various volume fractions. The aim of this study is to investigate following properties: 
1)To investigate the Strength properties of high strength fibre reinforced concrete composite with various volume fraction. Such as compressive strength, split tensile strength and Bond strength.

2) To compare the properties of these special controlled concrete with that of normal concrete.

\section{CRIMPED STEEL FIBRES}

The crimped steel fibers are made of either carbon steel or stainless steel. The ductility of metals makes possible their conversion into wire by drawing the metal through dies that become successively smaller. They are quite rigid materials and this rigidity imposes mechanical properties of High Strength Fibre Reinforced Concrete. However, the flexibility of materials is a function of the cross-sectional area by its aspect ratio. As the diameter of a rod is reduced by one-half, its flexibility is increased by a factor of four. The tensile strength ranges from 345 to $1380 \mathrm{Mpa}$. The minimum strength specified in ASTM is $345 \mathrm{Mpa}$. The modulus of elasticity for Steel fibre is 200 Gpa.Melting point is $1600^{\circ} \mathrm{C}$. The crimped fibre cross section may be circular and waving in cross sections. The length of the fibre is normally less than $150 \mathrm{~mm}$ even though longer fibres have been used. The length-diameter ratio typically ranges from 30 to 100 or more.

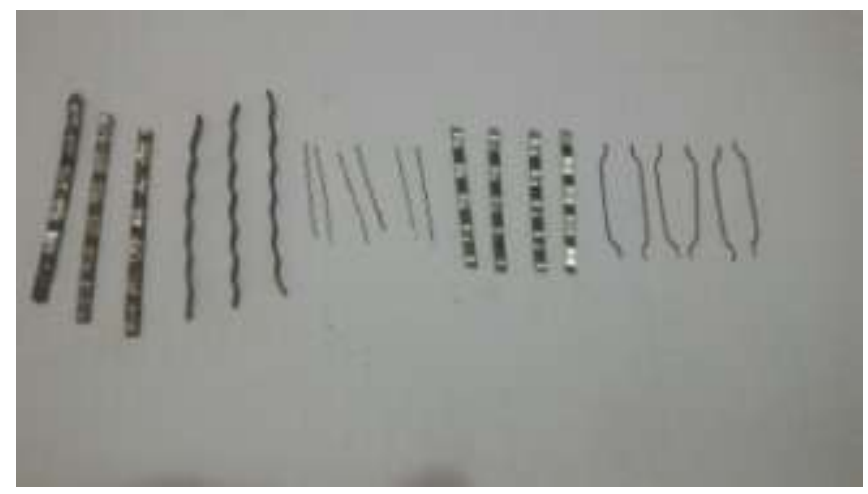

Fig 1: Different types of steel fibres used in HSFRC

\subsection{Factors Influencing High Strength Fibre}

\section{Reinforced Concrete}

The effective reinforcement of the matrix and the efficient transfer of stress between the matrix and the fibredepend upon many factors. Many of these factors are intimately interdependent, and exercise a profound but complex influence on the properties of the composite. Following are the factors stated.

- The relative fibre matrix stiffness

- Fibre matrix interfacial bond

- Strain compatibility between fibre and the matrix.

- Shape of fibres

- Strength of fibres

- Fibre orientation

- Specimen size

- Span of specimen

- Spacing of fibres

- Physical and mechanical properties of fibres

\section{LITERATURE SURVEY}

Recently there has been considerable need for improving the properties of high strength concrete with respect to strength, durability, ductility and performance as a structural material with cement to meet the requirements of the structure, such as strength and durability. This is because the conventional plain high strength concrete possesses high compressive strength, low tensile strength, poor impact strength, ductility, and little resistance to cracking and poor resistance to chemical attack. So it is necessary to overcome these drawbacks of high strength concrete. Continuous research by high strength concrete technologist to understand improve and develop the properties of concrete has resulted in a new type of concrete. Which, introduced fibres inside of concrete for improving strength, ductility, hardness and toughness is known as fiber reinforced high strength concrete. Fibre reinforced high strength concrete can be defined as a composite material consisting of mixtures of cement, sand, fly ash, silica fume, GGBS, aggregate and discontinuous, discrete, uniformly dispersed suitable fibres.Continuous meshes, woven fabrics and long wires or rods are not considered to be discrete Fibre.

Mullick, Walia and Sharma [6] studied the incorporation of randomly distributed, discrete, short polypropylene (PP) fibers in the matrix results in three-dimensional crack arrest and crack control system in the high strength concrete. Polypropylene (PP) fibres are alkali-proof, corrosion free and economical alternative to steel fibers. Relatively higher flexural strength, improved impact, fatigue and abrasion resistance, along with greater toughness and shock absorption capacity are observed. Bernard [8] suggested model of flexural resistance underpins most methods of thickness design for high strength concrete slabs-on-grade and other high strength concrete plate elements subject to point loading. Author demonstrated that the peak in load resistance associated with cracking of a FRC slab in bending couldn't be determined as a simple function of the Modulus OF Rupture (MOR) alone.Singh S.P.andKaushik S [10] worked on finding Fatigue strength of steel fiber reinforced concrete in flexural member.

\section{EXPERIMENTAL PROGRAM}

Ordinary Portland cement having 7 days compressive strength of $45.20 \mathrm{Mpa}$ and confirming to IS 12269-1987 and fine aggregate passing through $4.75 \mathrm{~mm}$ sieve and coarse aggregatespassing through $10 \mathrm{~mm}$ sieve whichconfirming to IS 383-1970 were used.The fineness modulus of sand was 2.803 and those of $10 \mathrm{~mm}$ coarse aggregate were 7.52 calculated in laboratory. All materials were tested in laboratory as per relevant IS codes. For making M-90 grade of high strength concrete having mix proportions 0.23: 1:0.99:1.52 i.e. in which $\mathrm{W} / \mathrm{C}$ ratio is 0.23 :Ordinary Portland cement is used by Ultratech cement. Fine Aggregate is used from Godavari River, Paithan: Coarse Aggregate is used from Sangavi Dist. Aurangabad. Silica Fume is brought from Rouff Supplier Canought place Cidco, Aurangaabad. Flash ash is collect from Dirk India Private Ltd., Nashik. Rouff Super plasticizer is used for as a water 
reducer in concrete. Following moulds and specimens were prepared for the testing purpose.

- Cubes of (100 X 100 X 100)mm size for compressive.

- Cylinder of diameter (150 X 300)mm in length.

All specimens were cast incorporating $0 \%$ to $4 \%$ steel fibres of weight of cement at the interval of $0.5 \%$ variation. The fly ash content is $23 \%$ and $7 \%$ silica fume keeping constant by weight of cement. Each material was weighted on waving gauge accurately before preparing dry mix.
Workability was measured at every time for wet concrete by using slum cone test. For each test six specimens were casted for 7 and 28 Days testing. Compaction of all these specimens was done using 25 blow of tamping rod at every layer and table vibrator to avoid balling of fibres. The specimens of normal High Strength concrete and high strength Fibre Reinforced Concrete were cured in curing tank for 7 and 28 days at normal temperature.Total specimens were tested on $2000 \mathrm{KN}$ Compression Testing Machine as per IS 516-1959.

Table 1: Cube Casting Schedule

\begin{tabular}{|l|l|l|l|l|l|l|l|l|}
\hline Mix des-ign & Silica Fume & Fly Ash & Flat Fibre cont-ent \% & W/C & \multicolumn{2}{|l|}{ Compressive Test } & \multicolumn{2}{l|}{ Split Tensile Test } \\
\hline & & & & & 7 days & 28 days & 7 days & 28 days \\
\hline M-90 & $7 \%$ & $23 \%$ & 0.0 & 0.23 & 3 & 3 & 3 & 3 \\
\hline M-90 & $7 \%$ & $23 \%$ & 0.5 & 0.23 & 3 & 3 & 3 & 3 \\
\hline M-90 & $7 \%$ & $23 \%$ & 1.0 & 0.23 & 3 & 3 & 3 & 3 \\
\hline M-90 & $7 \%$ & $23 \%$ & 1.5 & 0.23 & 3 & 3 & 3 & 3 \\
\hline M-90 & $7 \%$ & $23 \%$ & 2.0 & 0.23 & 3 & 3 & 3 & 3 \\
\hline M-90 & $7 \%$ & $23 \%$ & 2.5 & 0.23 & 3 & 3 & 3 & 3 \\
\hline M-90 & $7 \%$ & $23 \%$ & 3.0 & 0.23 & 3 & 3 & 3 & 3 \\
\hline M-90 & $7 \%$ & $23 \%$ & 3.5 & 0.23 & 3 & 3 & 3 & 3 \\
\hline M-90 & $7 \%$ & $23 \%$ & 4.0 & 0.23 & 3 & 3 & 3 & 3 \\
\hline
\end{tabular}

Total number Of Specimen $=108$

Table 2: Physical Properties Of Coarse Aggregate

\begin{tabular}{|l|l|l|}
\hline Sr.No & Particulars & $\begin{array}{l}\text { Coarse } \\
\text { Aggregate }\end{array}$ \\
\hline 1 & Density(compacted in Kg/cum) & 1830 \\
\hline 2 & Fineness Modulus & 7.53 \\
\hline 3 & Specific Gravity & 2.78 \\
\hline 4 & Water absorption (\%) & 1.60 \\
\hline 5 & Surface moisture & Nil \\
\hline
\end{tabular}

Table 3: Physical Properties Of Fineaggregate

\begin{tabular}{|l|l|l|}
\hline $\begin{array}{l}\text { Sr. } \\
\text { No }\end{array}$ & Particulars & $\begin{array}{l}\text { Fine } \\
\text { Aggregate }\end{array}$ \\
\hline 1 & Density (compacted in Kg/cum) & 1918 \\
\hline 2 & Fineness Modulus & 2.85 \\
\hline 3 & Specific Gravity & 2.58 \\
\hline 4 & Water absorption $(\%)$ & 1.21 \\
\hline 5 & Surface moisture & Nil \\
\hline
\end{tabular}

\subsection{Physical Properties of Crimped Steel Fibre}

Steawoolscrimped steel fibres were used for experimental work. Fibres are high tensile cold drawn wire and specially engineered for use in concrete. Fibres are made available from shaktimaan industries, Nagpur.
Table 4: Physical Properties Of Steel Fibre

\begin{tabular}{|l|l|l|}
\hline Sr.No. & Property & Value \\
\hline 1. & Diameter & 0.25 \\
\hline 2. & Length of fibre & $30 \mathrm{~mm}$ \\
\hline 3. & Appearance & Bright in clean wire \\
\hline 4. & Average aspect ratio & 120 \\
\hline 6. & Shape of the Fibre & Hooked ends bundles \\
\hline 7. & $\begin{array}{l}\text { Virgin fibre tensile } \\
\text { strength }\end{array}$ & $1050 \mathrm{MPa}$ \\
\hline 8. & Modulus of Elasticity & $200 \mathrm{GPa}$ \\
\hline 9. & Specific Gravity & 7.86 \\
\hline
\end{tabular}

Table 5: Properties Of Silica Fume Used

\begin{tabular}{|l|l|l|l|}
\hline \multirow{2}{*}{$\begin{array}{l}\text { Sr. } \\
\text { No. }\end{array}$} & Chemical Composition & \multicolumn{2}{l|}{} \\
\cline { 2 - 4 } & Parameters & Specification & Analysis \\
\hline 1 & Sio2 & Min. 85\% & 91.0 \\
\hline 2 & Moisture Content & Max. 3\% & 0.7 \\
\hline 3 & Loss of ignition @975C & Max. 6\% & 1.4 \\
\hline 4 & Carbon & Max. 2.5\% & 0.8 \\
\hline 5 & $>$ 45 micron & Max. 10\% & 0.4 \\
\hline 6 & Bulk Density & $\begin{array}{l}500-700 \\
\text { Kg/m3 }\end{array}$ & 640 \\
\hline
\end{tabular}


Table 6: Properties of Fly Ash Used

\begin{tabular}{|l|l|l|}
\hline $\begin{array}{l}\text { SR. } \\
\text { NO }\end{array}$ & Parameters & Specification \\
\hline $\mathbf{1}$ & Presentation & Finely dry powder \\
\hline 2 & Colour & Greyish white \\
\hline 3 & Bulk weight & $\mathbf{0 . 6 5 t o n n e} / \mathbf{m} 3$ \\
\hline 4 & Specific density & $\mathbf{2 . 3 m e t r i c ~ t o n ~ p e r ~ c u b i c ~ m e t r e ~}$ \\
\hline 5 & Loss of ignition & $<2.5 \%$ \\
\hline 6 & Particle size & $\begin{array}{l}\text { Less than 5\% retained on } \mathbf{2 5} \\
\text { micron sieve }\end{array}$ \\
\hline 7 & Particle shape & Spherical \\
\hline 8 & Package & $\mathbf{3 0 k g}$ bags \\
\hline 9 & Water demand & $\mathbf{8}$ to $10 \%$ Reduction \\
\hline
\end{tabular}

\subsection{Mix Design of Concrete}

DOE method of mix design was use for M-90 grade of concrete. The quantity of ingredient materials and mix properties is for design is as follows.

Table 7: Mix Design Ratios

\begin{tabular}{|l|l|l|l|}
\hline $\begin{array}{l}\text { Sr. } \\
\text { No. }\end{array}$ & Material & $\begin{array}{l}\text { Proportion by } \\
\text { weight }\end{array}$ & Weight in $\mathbf{k g}$ \\
\hline 1 & Cement & 1 & 695 \\
\hline 2 & F.A. & $\mathbf{0 . 9 9}$ & 688 \\
\hline 3 & C.A. & 1.52 & 1057 \\
\hline 4 & W/C ratio & $\mathbf{0 . 2 3}$ & 160 \\
\hline
\end{tabular}

Replacement of cement by $23 \%$ by Flyash respectively

\subsection{Testing of Specimen}

Workability of wet concrete is determined by slump cone test and bulk density is calculated by taking weight of concrete cylinder in wet state. Table shows the results of workability and wet density of various concrete mixes.Compressive strength of cubes are determined at 7 days and 28 days using Compressive testing machine (CTM) of capacity $2000 \mathrm{KN}$. Split tensile test, flexure test are carried out on universal testing machine of 40 tones capacity.

\subsection{Compressive Strength Test on Cube}

A cube compression test performed on standard cubes of plain and HSFRC of size $100 \times 100 \times 100 \mathrm{~mm}$ after 7 days and 28 days of immersed in water of curing plain concrete and HSFRC specimens. Results are shown in Table (4.2) and graphical presentation between compressive strength and percentage of fibre shown on bar chart in Fig. (4.1).

The compressive strength of specimen was calculated by the following formula:

$F_{c u}=P_{c} / A$

Where, $P_{c}=$ Failure load in compression, $\mathrm{KN}$

$A=$ Loaded area of cube, $\mathrm{mm}^{2}$

\subsection{Split Tensile Test on Cylinder}

The split tensile test is well known test, which is indirectly used to determine the tensile strength of concrete. Due to difficulties involved in conducting the direct tension test, a number of indirect methods have been developed to determine the tensile strength of concrete.

The tensile strength is conducted on cylinder. It keeps in CTM by using two steel rods, at bottom and top for creating tensile forces in member. After loading when failure occurs is the tensile strength of concrete. The arrangement for the test is shown in photo with the pattern of failure. The split tensile strength of cylinder is calculated by the following formula.

$f_{\mathrm{t}}=2 \mathrm{P} / \pi \mathrm{LD}$

$f_{\mathrm{t}}=$ Tensile strength, MPa , P = Load at failure, $\mathrm{N}$

$\mathrm{L}=$ Length of cylinder, $\mathrm{mm}$,

$\mathrm{D}=$ Diameter of cylinder, $\mathrm{mm}$.

\section{EXPERIMENTAL ANALYSIS}

The tests on hardened concrete are carried out according to relevant standards wherever applicable. Results of various strengths are computed according to the strength of material theory. Various tables presented in this paper shows the results obtained from the various tests on hardened concrete. Results of harden HSFRC are discussed in comparison with those of normal high strength concrete.

\subsection{Compressive Strength Test on Cube}

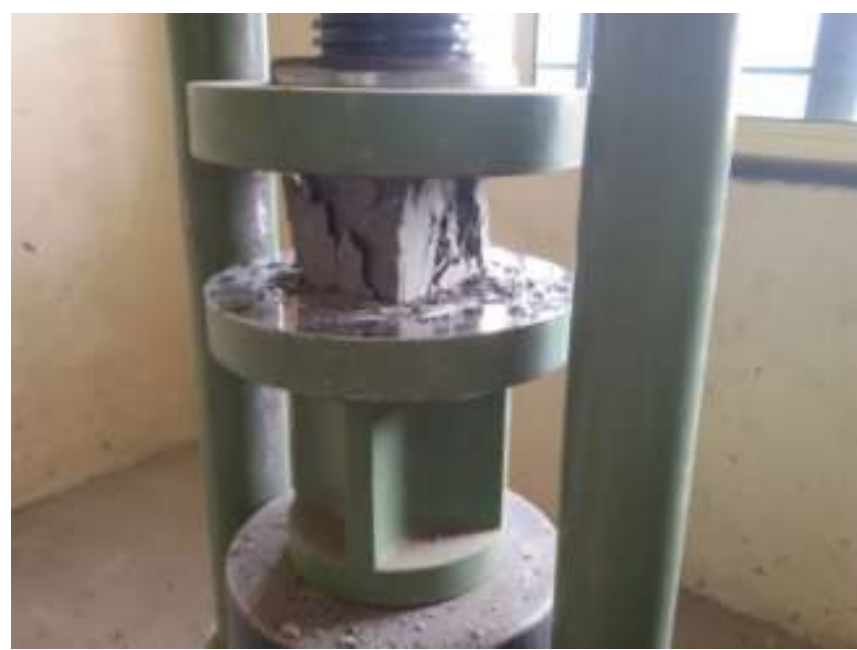

Fig 2. Compressive Test on Concrete Cube

The results of compressive strength on cubes with crimpedsteel fibres are obtained using Equation (1). The specimen is tested as per IS 516-1959and presented in Table No.8 for 7 and 28 days cured in potable water which available in concrete technology laboratory. 
Table 8: Compressive Strength of Concrete, Mpa

\begin{tabular}{|c|c|c|c|c|c|}
\hline \multirow[t]{2}{*}{$\begin{array}{l}\text { Sr. } \\
\text { No. }\end{array}$} & \multirow[t]{2}{*}{$\begin{array}{l}\text { Mix. } \\
\text { desi. }\end{array}$} & \multirow[t]{2}{*}{$\begin{array}{l}\text { Microsilica } \\
\text { \& Fly ash } \\
\text { content } \\
(\%)\end{array}$} & \multirow[t]{2}{*}{$\begin{array}{l}\text { Fibre } \\
\text { Content } \\
\left(V_{f}\right) \%\end{array}$} & \multicolumn{2}{|c|}{$\begin{array}{l}\text { Compressive } \\
\text { Strength } \\
\left(f_{c u}\right) \\
(\mathbf{M P a})\end{array}$} \\
\hline & & & & 7days & 28 days \\
\hline 1 & M0 & $7+23$ & 0.0 & 63.50 & 90.02 \\
\hline 2 & M1 & $7+23$ & 0.5 & 64.70 & 90.10 \\
\hline 3 & M2 & $7+23$ & 1.0 & 65.78 & 91.40 \\
\hline 4 & M3 & $7+23$ & 1.5 & 65.80 & 91.60 \\
\hline 5 & M4 & $7+23$ & 2.0 & 66.10 & 92.30 \\
\hline 6 & M5 & $7+23$ & 2.5 & 66.20 & 92.50 \\
\hline 7 & M6 & $7+23$ & 3.0 & 66.35 & 93.15 \\
\hline 8 & M7 & $7+23$ & 3.5 & 66.40 & 94.30 \\
\hline 9 & M8 & $7+23$ & 4.0 & 66.10 & 93.10 \\
\hline
\end{tabular}

Results of cube compressive strength are shown in above Table. The 7 days and 28 days compressive strength is increased continuously with increase in fibre content up to $3.5 \%$ of fibre volume content in HSC. The Maximum Strength occurred is $66.40 \mathrm{Mpa}$ and $94.30 \mathrm{Mpa}$ at $3.5 \%$ of Fibre volume fraction in HSC. Hence the fibres are suitable for improving the compressive strength of High Strength structural concrete.

\subsection{Split Tensile Strength on Cylinder}

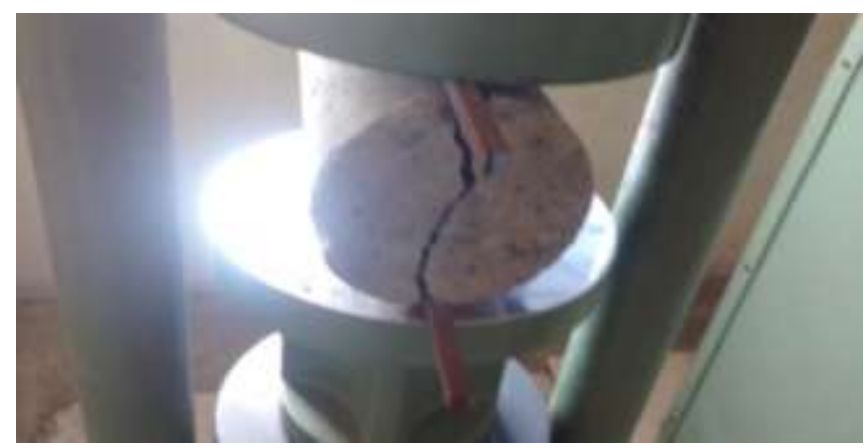

Fig 3 Split Tensile Test on Cylinder

Results of Split tensile strength on concrete with Crimpedsteel fibers are obtained from equation (2).The specimen is tested as per IS 516-1959 and presented in Table No. 9 for 7 and 28 days curedin potable water which available in concrete technology laboratory.

Table 9: SPLIT TENSILE STRENGTH ON CYLINDER, (MPA)

\begin{tabular}{|c|c|c|c|c|c|}
\hline \multirow[t]{2}{*}{$\begin{array}{l}\text { Sr. } \\
\text { No. }\end{array}$} & \multirow[t]{2}{*}{$\begin{array}{l}\text { Mix. } \\
\text { desi. }\end{array}$} & \multirow[t]{2}{*}{$\begin{array}{l}\text { Microsilica } \\
\text { \& Fly ash } \\
\text { content } \\
(\%)\end{array}$} & \multirow[t]{2}{*}{$\begin{array}{l}\text { Fibre } \\
\text { Content } \\
\left(V_{f}\right) \%\end{array}$} & \multicolumn{2}{|c|}{$\begin{array}{l}\text { Split Tensile } \\
\text { Strength of } \\
\text { Concrete }\left(F_{t}\right) \\
(\mathrm{MPa})\end{array}$} \\
\hline & & & & 7 days & 28 days \\
\hline 1 & M0 & $7+23$ & 0 & 5.50 & 7.22 \\
\hline 2 & M1 & $7+23$ & 0.5 & 6.44 & 7.95 \\
\hline 3 & M2 & $7+23$ & 1.0 & 7.54 & 8.11 \\
\hline 4 & M3 & $7+23$ & 1.5 & 7.90 & 9.07 \\
\hline 5 & M4 & $7+23$ & 2.0 & 8.11 & 9.62 \\
\hline 6 & M5 & $7+23$ & 2.5 & 8.65 & 10.43 \\
\hline 7 & M6 & $7+23$ & 3.0 & 9.25 & 11.26 \\
\hline 8 & M7 & $7+23$ & 3.5 & 8.91 & 10.12 \\
\hline 9 & M8 & $7+23$ & 4.0 & 8.77 & 9.76 \\
\hline
\end{tabular}

From the above Table the 7 and 28 days split tensile strength of fiber reinforced concrete with crimped shaped steel fibers is $9.25 \mathrm{Mpa}$ and $11.26 \mathrm{Mpa}$ at $3 \%$ of fibre volume fibre content in HSC. It means the tensile strength increases with increase in the percentage of fiber content in HSC. Hence the fibres are suitable for improving the split tensile strength of structural concrete by bridging internal cracks of concrete.

\section{CONCLUSION}

Following conclusion is based on the experimental study and results obtained.

- The maximum percentage increase in compressive strengths is at $3.5 \%$ of fibre volume fractions and Split tensile strength is achieved at $3 \%$ of fibre volume fractions.

- The fibres observed on the failure section of the cylinder in split test are found to be aligned along the length of the cylinder.

\section{SCOPE FOR FUTURE WORK}

The present work has good scope for future research. Some of the research areas are as follows:

1. Behaviour of HSFRC with low volume fraction of fibres.

2. Behaviour under creep and shrinkage.

3. Behaviour under temperature effect for same fibre content.

4. Behaviour under freeze and thaw effect.

5. Same parameters with recycled aggregates.

6. Fracture mechanics.

\section{REFERENCES}

[1] S. Bhaskar, RavindraGettu, B. H. Bharatkumar and M. Neelamegam, "Strength, bond and durability relate properties of concrete with mineral admixtures", Indian Concrte Journal, February- 2012, pp.09-16.

[2] VivekBindiganavile, FarnazBatool and Narayana Suresh, "Effect of fly ash on thermal properties of cement based foams evaluated by transient plane heat source", Indian Concrte Journal, November, 2012, pp.07-13.

[3] SubhashMitra, Pramod K. Gupta and Suresh C. Sharma, "Time- dependant strength gain in mass concrete using mineral admixtures", Indian Concrte Journal, November, 2012, pp.15-22.

[4] Avinash S. Pant and Suresh R. Parekar, "Steel fibres reinforced concrete beams withour reinforcement under combined bending, shear and torsion", Indian Concrete Journal, April, 2012, pp.39-43

[5] D. G. Kadkade and P. K. Mishra." Fly ash blended cement for concrete pavements", Indian Concrete Journal, March, 2012, pp.17-24

[6] Mullick A. K., Walia P. and Sharma S. N., "Applications of Polypropylene Fiber reinforced High strength concrete (PFRC) With Vacuum Processing", Advances in Bridge Engineering, Vol. 8, No. 2, 2006, pp.123-129. 
[7] Bernard, "Influence of toughness on the apparent cracking load of fibre reinforced high strength concrete slabs", Journal of Structural Engineering ASCE, Vol. 132, No. 12, 2006.

[8] Job Thomas and AnanthRamaswamy, "Mechanical Properties of Steel Fiber-Reinforced Concrete", Journal of Materials in Civil Engineering, Vol. 19, No. 5, May 1, 2007, pp. 385-389.

[9] Sueki S., Soranakom C.,Mobasher B., Peled A., “ Pull out slip response of Fabrics Embedded in a cement paste matrix", Journal of Materials in Civil Engineering ASCE, Vol. 19, No. 9, 2007, pp.718-726.

[10] Singh S.P.andKaushikS.K.,"Fatigue strength of steel fiber reinforced concrete in flexure". Cement \& Concrete Composites, Vol. 25, 2003, pp. 779-786.

[11] IS 516-1959Method of Tests for Strength of Concrete

[12] IS12269-1987: Specification for 53 grade ordinary Portland cement

[13] IS383 (1970): Specification for Coarse and Fine Aggregates.

[14] Concrete Technology by M. S, Shetty. 